\title{
SHORT AND LONG-TERM IMPACTS OF US FISCAL STIMULUS ON US INCOME
}

\author{
Deergha Raj Adhikari, University of Louisiana at Lafayette, LA, U.S.A.
}

\author{
dx.doi.org/10.18374/JIFE-21-2.2
}

\begin{abstract}
Our study examines the impact of US government's stimulus spending on the nation's income. We apply the VECM model on US data from 1980 to 2020. We also estimate impulse response of our model variables by giving one standard deviation positive shock to each of our model variables. From our VECM estimates as well as impulse responses, we find that, while the long-term impact of US fiscal stimulus spending on US GDP is positive and significant, the short-term effect is insignificant.
\end{abstract}

Keywords: fiscal stimulus spending, stationarity, cointegration, VECM, short-term impact, long-term impact 